\title{
Hubungan Kadar Lipid Serum dengan Nilai Estimasi Laju Filtrasi Glomerulus pada Penyakit Ginjal Kronik
}

\author{
${ }^{1}$ Claudia E. Senge \\ ${ }^{2}$ Emma Sy. Moeis \\ ${ }^{2}$ Cerelia E. C. Sugeng
}

\author{
${ }^{1}$ Kandidat Skrispi Fakultas Kedokteran Univeritas Sam Ratulangi Manado \\ ${ }^{2}$ Bagian Obstetri-Ginekologi Fakultas Kedokteran Universitas Sam Ratulangi Manado \\ Email: claudiaericho@ rocketmail.com
}

\begin{abstract}
Chronic kidney disease (CKD) is a health problem in the world and the number of patients continues to increase. The results of health research data base (Riskesdas) in 2013 suggested that the prevalence of CKD in Indonesia amounted to $0.2 \%$. Riskesdas mentioned three provinces with the highest CKD cases in Indonesia, as follows: Central Sulawesi 0.5\%, North Sulawesi $0.4 \%$, and Gorontalo $0.4 \%$. Dyslipidemia is characterized by the progressive increase in triglyceride rich lipoproteins (Tg), low density lipoprotein (LDL) and decreased high density lipoprotein (HDL), often associated with CKD and contributes to increased cardiovaskular risk. Various experimental studies also show that lipid abnormalities may aggravate the progression of kidney damage. Glomerular filtration rate (GFR) is one of the examination of kidney function in assessing the function of excretion that calculate the amount of filtrate which can be produced by the glomeruli. Decreased levels of LFG indicates the severity of kidney damage. This study was aimed to determine the relationship between serum lipid levels (total cholesterol, HDL, LDL, Tg) and eLFG in outpatients with CKD at Kidney-Hypertension Polyclinic of Prof Dr. R. D. Kandou Hospital Manado. This was a descriptive analytical study with a cross sectional retrospective design using data of the medical records of patients with CKD at Prof Dr. R. D. Kandou Hospital Manado. The study population was patients with CKD 4, CKD 5 ND, and CKD 5 HD. Samples were patients diagnosed as CKD outpatients at Kidney-Hypertension Polyclinic of Prof Dr. R. D. Kandou Hospital from July 2015 to July 2016. The relationships between the study variables were analyzed with Spearman-rho test. The relationships of the variables were as follows: total cholesterol and eLFG showed the $r$ value of -0.279 ( $p=0.039$ ); HDL and eLFG showed the $r$ value of $-0.024(p=0.863)$; LDL and eLFG showed the $r$ value of $-0.287(p=0.034)$; triglycerides and eLFG showed the $r$ value of $0.293(p=0.039)$. Conclusion: There was a significant negative

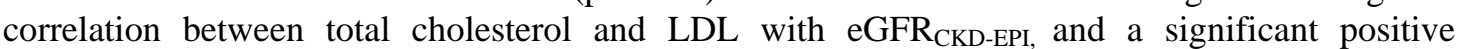
correlation between triglyceride and eGFR $\mathrm{CKD}_{\mathrm{CPI}}$
\end{abstract}

Keywords: CKD, total cholesterol, HDL, LDL, Tg, eGFR ${ }_{\text {CKD-EPI }}$

\begin{abstract}
Abstrak: Penyakit Ginjal Kronik (PGK) merupakan salah satu masalah kesehatan di dunia, dimana jumlah penderita terus meningkat. Hasil data riset kesehatan dasar (Riskesdas) tahun 2013 mengemukakan bahwa prevalensi PGK di Indonesia sebesar 0,2\%. Riskesdas menyebutkan tiga provinsi dengan kasus PGK tertinggi di Indonesia adalah provinsi Sulawesi Tengah 0,5\%, Sulawesi Utara $0,4 \%$ dan Gorontalo $0,4 \%$. Displidemia ditandai oleh adanya peningkatan lipoprotein kaya trigliserida (Tg), Low Density Lipoprotein (LDL), dan penurunan High Density Lipoprotein (HDL), sering berhubungan dengan PGK dan berkontribusi pada peningkatan resiko kardiovaskular. Laju filtrasi glomerulus (LFG) merupakan salah satu pemeriksaan fungsi ginjal dalam menilai fungsi ekskresi, dengan cara menghitung banyaknya filtrat yang dapat dihasilkan oleh glomerulus. Derajat penurunan kadar LFG menandakan beratnya kerusakan ginjal. Penelitian ini bertuujuan untuk mengetahui hubungan kadar lipid serum (kolesterol total, HDL, LDL, Tg) dengan eLFG pada subyek PGK yang rawat jalan di Poliklinik Ginjal-Hipertensi RSUP Prof. Dr. R. D. Kandou Manado. Jenis penelitian ialah deskriptif analitik dengan desain potong lintang retrospektif menggunakan data rekam medis pasien PGK di RSUP Prof. Dr. R. D. Kandou
\end{abstract}


Manado. Populasi penelitian ialah pasien PGK 4, PGK 5 ND dan PGK 5 HD. Sampel penelitian ialah pasien dengan diagnosis PGK yang rawat jalan di Poliklinik Ginjal - Hipertensi RSUP Prof. dr. R. D. Kandou Manado pada periode Juli 2015-Juli 2016. Hubungan antara variabel penelitian digunakan uji korelasi Spearmen-rho. Hasil penelitian hubungan kolesterol total dan eLFG mendapatkan nilai $r=-0,279$ dengan $\mathrm{p}=0,039$. Untuk hubungan HDL dan eLFG didapatkan nilai $\mathrm{r}=-0,024$ dengan $\mathrm{p}=0,863$. Untuk hubungan LDL dan eLFG didapatkan nilai $\mathrm{r}=-0,287$ dengan $\mathrm{p}=$ 0,034 dan untuk Tg dan eLFG didapatkan nilai $\mathrm{r}=0,293$. Simpulan: Terdapat hubungan korelasi negatif bermakna antara kolesterol total dan $\mathrm{LDL}$ dengan $\mathrm{LFG}_{\mathrm{CKD}-\mathrm{EPI}}$ serta hubungan korelasi positif bermakna antara trigliserida dengan eLFG $\mathrm{CKD}_{\mathrm{C} \text {-EPI }}$

Kata kunci: penyakit ginjal kronik, kolesterol total, $\mathrm{HDL}, \mathrm{LDL}, \mathrm{Tg}, \mathrm{eLFG}_{\mathrm{CKD}-\mathrm{EPI}}$

Penyakit ginjal kronik (PGK) didefinisikan sebagai kerusakan ginjal yang terjadi lebih dari 3 bulan,berupa kelainan struktural atau fungsional, dengan atau tanpa penurunan laju filtrasi glomerulus (LFG). Definisi lain dari PGK yaitu penurunan LFG $<60$ $\mathrm{ml} / \mathrm{menit} / 1.73 \mathrm{~m}^{2}$ selama 3 bulan, dengan atau tanpa kerusakan ginjal. ${ }^{1,2}$

Penyakit ginjal kronik merupakan salah satu masalah kesehatan di dunia dengan jumlah penderita terus meningkat. Data tahun 1995-1999 di Amerika Serikat menyatakan insidens PGK diperkirakan 100 kasus perjuta penduduk pertahun, dan angka ini meningkat sekitar $8 \%$ setiap tahunnya. ${ }^{3}$ Hasil data riset kesehatan dasar (Riskesdas) tahun 2013 mengemukakan bahwa prevalensi PGK di Indonesia sebesar $0,2 \%$. Riskesdas menyebutkan tiga provinsi dengan kasus PGK tertinggi di Indonesia adalah provinsi Sulawesi Tengah $0,5 \%$, Sulawesi Utara $0,4 \%$ dan Gorontalo $0,4 \%$. Berdasarkan data di berbagai pusat nefrologi diIndonesia prevalensi PGK berkisar 200-250 penduduk per satu juta penduduk, sedangkan data yang diperoleh Dinas Kesehatan Indonesia, PGK berada pada posisi enam dari sepuluh penyakit utama penyebab kematian di rumah sakit tahun 2006, dengan angka kematian sebesar 2.521 atau $2,99 \%$ dari total kematian di rumah sakit (Departemen Kesehatan RI 2008). ${ }^{4,5}$

Gambaran klinis PGK sesuai dengan penyakit yang mendasari seperti diabetes melitus, infeksi traktus urinarius, batu traktus urinarius, hipertensi, hiperurisemia, lupus eritematosus dan lainnya. Pada pasien PGK dapat dijumpai sindrom uremia yang terdiri dari lemah, letargi, anoreksia, mual muntah, nokturia, kelebihan volume cairan (volume overload), neuropati perifer dan pruritus. $^{2}$ Displidemia ditandai oleh adanya penigkatan lipoprotein kaya Trigliserida (Tg), Low Density Lipoprotein (LDL) dan penurunan High Density Lipoprotein (HDL), sering berhubungan dengan PGK dan berkontribusi pada peningkatan risiko kardiovaskular. Pada berbagai penelitian eksperimental juga menunjukkan bahwa abnormalitas lipid bisa memperburuk progresivitas kerusakan pada ginjal. ${ }^{6}$

Laju filtrasi glomerulus (LFG) merupakan salah satu pemeriksaan fungsi ginjal dalam menilai fungsi ekskresi, dengan cara menghitung banyaknya filtrat yang dapat dihasilkan oleh glomerulus. Derajat penurunan kadar LFG menandakan beratnya kerusakan ginjal. ${ }^{2,7}$ Penentuan fungsi ginjal dengan menggunakan rumus dapat memperkirakan nilai LFG menjadi lebih mudah, cepat, dan praktis. Penentuan estimasi Laju filtrasi glomerulus (eLFG) terdiri dari formula eLFG berdasarkan rumus dari Cockroft-Gault (eLFG $\mathrm{CG}$, eLFG berdasarkan rumus dari Modification of Diet in Renal Disease (eLFG ${ }_{\mathrm{MDRD}}$ ) dan eLFG berdasarkan rumus dari The Chronic Kidney Disease Epidemiology Collaboration (eLFG $\left.{ }_{\text {CKD-EPI }}\right)^{8}$ Penelitian oleh kelompok Chronic Kidney Disease Epidemiology Collaboration mempublikasikan formula perhitungan eLFG yaitu

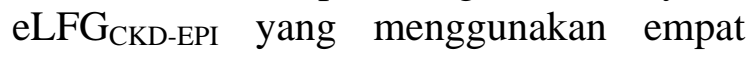
variabel yaitu kadar kreatinin serum, umur, jenis kelamin dan ras. Formula ini memiliki akurasi yang lebih baik dimana dapat digunakan pada LFG $<60 \mathrm{~mL} /$ menit/ $1,73 \mathrm{~m}^{2} \cdot{ }^{9-1}$ 
Berdasarkan latar belakang diatas, penelitian ini dilakukan untuk mengetahui hubungan kadar lipid serum dengan eLFG ${ }_{\text {CKD-EPI }}$ pada subyek PGK yang rawat jalan di Poliklinik Ginjal-Hipertensi RSUP Prof. Dr. R. D. Kandou Manado.

\section{METODE PENELITIAN}

Jenis penelitian ini ialah deskriptif analitik dengan desain potong lintang retrospektif yang menggunakan data rekam medis pasien PGK rawat jalan di Poliklinik Ginjal-Hipertensi RSUP Prof. Dr. R. D. Kandou Manado. Penelitian ini dilakukan di Poliklinik Ginjal-Hipertensi RSUP Prof. Dr. R. D. Kandou Manado selama bulan Oktober-November 2016. Populasi dalam penelitian ialah pasien PGK 4, PGK 5 ND, dan PGK 5 HD. Sampel penelitian ialah pasien dengan diagnosis PGK yang rawat jalan di Poliklinik Ginjal-Hipertensi RSUP Prof. Dr. R. D. Kandou Manado pada periode Juli 2015-Juli 2016. Pengolahan data dilakukan secara manual dengan mencatat data dari rekam medik kemudian data ditabulasikan dan ditampilkan dengan bentuk tabel dan tulisan serta menggunakan program for social science (SPSS).

\section{HASIL PENELITIAN}

Penelitian ini dilakukan pada pasien penyakit ginjal kronik yang rawat jalan di Poliklinik Ginjal-Hipertensi RSUP Prof. Dr. R. D. Kandou Manado periode Juli 2015 - Juli 2016 dan didapatkan 55 sampel penelitian.

Tabel 1 memperlihatkan eLFG nilai minimum ialah 2,30, maksimum 18,40, rerata 7,37 dengan simpangan baku 3,73. Pada kolesterol total nilai minimum ialah 63,00 , maksimum 273,00 , rerata 164,30 dengan simpangan baku 47,18. Pada HDL nilai minimum ialah 8,00 maksimum 74,00, rerata 36,50 dengan simpangan baku 14,62. Pada LDL nilai minimum ialah 28,00, maksimum 211,00 , rerata 102,00 dengan simpangan baku 38,66. Pada Trigliserida nilai minimum ialah 43,00, maksimum 298,00 rerata 131,30 dengan simpangan baku 53,18 .

Tabel 1. Karakteristik variabel penelitian

\begin{tabular}{lllll}
\hline & Min & Maks & \multicolumn{1}{c}{ Rerata } & \multicolumn{1}{c}{ SB } \\
\hline Umur (Tahun) & 15,00 & 87,00 & 54,40 & 12,60 \\
Hemoglobin (g/dL) & 2,60 & 11,60 & 9,0144 & 1,641 \\
Leukosit (/uL) & 3254,0 & $19,400,00$ & 8443,41 & 3552,40 \\
Trombosit (pg) & 34000,00 & 579000,00 & 21959,29 & 94011,14 \\
Ureum (mg/dL) & 27,00 & 386,00 & 126,94 & 68,22 \\
Kreatinin (mg/dL) & 1,70 & 15,90 & 7,87 & 3,36 \\
eLFG CKD-EPI $_{\text {Kol Total (mg/dL) }}$ & 2,30 & 18,40 & 7,37 & 7,73 \\
HDL (mg/dL) & 63,00 & 273,00 & 164,30 & 47,18 \\
LDL (mg/dL) & 28,00 & 74,00 & 36,50 & 14,62 \\
Tg (mg/dL) & 43,00 & 211,00 & 102,0 & 38,66 \\
Asam Urat & 3,10 & 298,00 & 131,30 & 53,18 \\
\hline
\end{tabular}

Ket $:$ Min $=$ nilai minimum, Maks $=$ nilai maksimum, rerata $=$ nilai rata-rata, $\mathrm{SB}=$ simpangan baku

Tabel 2 menunjukkan bahwa sebagian besar responden penelitian berada pada kelompok umur 51-60 tahun berjumlah 21 orang $(38,2 \%)$ sedangkan yang paling sedikit ialah kelompok umur $\leq 21$ tahun dan $\geq 80$ tahun masing-masing berjumlah 1 responden $(1,8 \%)$.

Tabel 3 menunjukkan bahwa sebagian besar jenis kelamin responden penelitian adalah perempuan berjumlah 29 responden 
$(52,7 \%)$ sedangkan jenis kelamin laki-laki berjumlah 26 responden $(47,3 \%)$.

Tabel 2. Distribusi sampel berdasarkan umur

\begin{tabular}{cc}
\hline Umur (Tahun) & $\mathbf{n}$ \\
\hline$\leq 21$ & 1 \\
$21-30$ & 2 \\
$31-40$ & 5 \\
$41-50$ & 10 \\
$51-60$ & 21 \\
$61-70$ & 10 \\
$71-80$ & 5 \\
$\geq 80$ & 1 \\
Total & 55 \\
\hline
\end{tabular}

Tabel 3. Distribusi sampel berdasarkan jenis kelamin

\begin{tabular}{lcc}
\hline Jenis kelamin & n & \% \\
\hline Laki-laki & 26 & 47,3 \\
Perempuan & 29 & 52,7 \\
Total & 55 & 100 \\
\hline
\end{tabular}

Tabel 4 menunjukkan bahwa sebagian besar nilai eLFG responden penelitian $<15$ adalah berjumlah 52 responden $(94,6 \%)$ sedangkan nilai eLFG $15-30$ berjumlah 3 responden $(5,4 \%)$.

Tabel 4. Karakteristik berdasarkan stadium

\begin{tabular}{lcc}
\hline Stadium & n & $(\boldsymbol{\%})$ \\
\hline PGK 4 & 3 & $5,4 \%$ \\
PGK 5 ND & 9 & $16,3 \%$ \\
PGK 5 HD & 43 & $78,1 \%$ \\
Total & 55 & $100 \%$ \\
\hline
\end{tabular}

\section{Uji Analisis Statistik Penelitian}

Berdasarkan Tabel 5 dapat dilihat terdapat hubungan antara kolesterol total dengan eLFG $(\mathrm{r}=-0,279, p=0,039)$.

Berdasarkan Tabel 6 dapat dilihat tidak terdapat hubungan antara HDL dengan eLFG dengan nilai $r$ sebesar $-0,024$ dan nilai $p=0,863(>0,05)$.

Tabel 5. Hubungan kadar kolesterol total dengan nilai eLFG

\begin{tabular}{lccc}
\hline Variabel & n & Koefisien korelasi & Kemaknaan \\
\hline${\text { Kol T }- \text { eLFG }_{\text {CKD-EPI }}}^{55}$ & $\mathrm{r}=-0,279$ & $p=0,039$ \\
\hline
\end{tabular}

Tabel 6. Hubungan kadar HDL dengan nilai eLFG

\begin{tabular}{lccc}
\hline Variabel kemaknaan & n & Koefisien korelasi \\
\hline HDL - LLFG $_{\text {CKD-EP }}$ & 55 & $\mathrm{r}=-0,02$ & $p=0,863$
\end{tabular}

Berdasarkan Tabel 7 dapat dilihat terdapat hubungan antara LDL dengan eLFG dengan nilai $r$ sebesar $-0,287$ dan nilai $p=0,034(<0,05)$.

Tabel 7. Hubungan kadar LDL dengan nilai eLFG

\begin{tabular}{|c|c|c|}
\hline $\begin{array}{l}\text { Variabel } \\
\text { kemaknaan }\end{array}$ & $\mathbf{n}$ & $\begin{array}{l}\text { Koefisien } \\
\text { korelasi }\end{array}$ \\
\hline LDL - eLFG ${ }_{\text {CKD-EPI }}$ & 55 & $\mathrm{r}=-0,287 \mathrm{p}=0,034$ \\
\hline
\end{tabular}

Berdasarkan Tabel 8 dapat dilihat terdapat hubungan antara trigliserida dengan eLFG dengan nilai $r$ sebesar 0,293 dan nilai $\mathrm{p}=0,030(<0,05)$.

Tabel 8. Hubungan kadar trigliserida dengan nilai eLFG

\begin{tabular}{lll}
\hline $\begin{array}{l}\text { Variabel } \\
\text { Kemaknaan }\end{array}$ & $\mathbf{n}$ & $\begin{array}{l}\text { Koefisien } \\
\text { korelasi }\end{array}$ \\
\hline $\mathrm{Tg}-\mathrm{eLFG}_{\mathrm{CKD}-\mathrm{EPI}}$ & 55 & $\mathrm{r}=0,293 \quad \mathrm{p}=0,030$ \\
\hline
\end{tabular}

\section{BAHASAN}

Penyakit ginjal kronik merupakan salah satu faktor resiko untuk terjadinya penyakit kardiovaskular (PKV) yang secara tidak langsung berhubungan dengan morbiditas dan mortalitas. ${ }^{12}$ LFG 
merupakan salah satu pemeriksaan fungsi ginjal dalam menilai fungsi ekskresi, dengan cara mengukur banyaknya filtrat yang dapat dihasilkan oleh glomerulus. Penurunan kadar eLFG menandakan beratnya kerusakan ginjal. ${ }^{1,7}$ Beberapa penyakit yang berhubungan dengan risiko kardiovaskular meliputi DM, hipertensi dan hyperlipidemia. Faktor risiko yang berasal dari ginjal yaitu uremia atau dialisis dan faktor eksternal yang berpengaruh seperti proteinuria, volume overload yang kronik, peningkatan rennin angiotensin system activity (RAAS), inflamasi, infeksi, stress oksidatif, perubahan metabolisme kalsium dan fosfat, anemia dan malnutrisi. ${ }^{13}$

Displidemia yang ditandai oleh adanya peningkatan lipoprotein kaya trigliserida, LDL dan penurunan HDL, sering berhubungan dengan PGK dan berkontribusi pada peningkatan resiko kardiovaskular. Pada berbagai penelitian eksperimental juga menunjukkan bahwa abnormalitas lipid bisa memperburuk progresivitas kerusakan pada ginjal. ${ }^{6}$ Dalam penelitian ini bertujuan untuk mengetahui hubungan antara kadar lipid serum( kolesterol total, HDL, LDL, Tg) dengan eLFG pada subyek penyakit ginjal kronik.

Pada Tabel 9 kadar kolesterol total yang didapatkan nilai minimum adalah 63,00, maksimum 273,00, rerata 164,30. Hasil penelitian di poliklinik Ginjal Hipertensi RSUP Prof. Dr. R. D. Kandou Manado, mendapatkan bahwa terdapat korelasi negatif bermakna $(r=-0,279, p=$ $0,039)$, artinya semakin tinggi kadar kolesterol total, maka semakin rendah nilai eLFG. Penyakit ginjal dapat meningkatkan kadar lipid dan keadaan abnormalitas lipid berhubungan dengan risiko kardiovaskular. Pada pasien dengan PGK dan peningkatan kadar kolesterol total, dapat terjadi secara sekunder karena kehilangan protein dan urin. Peningkatan kadar kolesterol total dan abnormalitas lipid berperan pada kerusakan glomerulus.

Pada Tabel 10 kadar HDL yang didapatkan nilai minimum adalah 8,00 maksimum $74,00, \quad$ rerata 36,50 menunjukkan hubungan antara kadar HDL dengan eLFG. Hasil penelitian di poliklinik Ginjal-Hipertensi RSUP Dr. R. D. Kandou Manado, mendapatkan bahwa tidak terdapat hubungan antara kadar HDL dengan eLFG pada pasien PGK ( $p=$ 0,863 . Proses pembentukkan dari HDL yaitu HDL dilepaskan sebagai partikel kecil miskin kolesterol yang mengandung apolipoprotein (Apo) A, C dan E dan disebut HDL nascent. HDL nascent berasal dari usus halus dan hati, mempunyai bentuk gepeng dan mengandung apolipoprotein A I. HDL nascent akan mendekati makrofag untuk mengambil kolesterol yang tersimpan di makrofag. Setelah mengambil kolesterol dari makrofag, HDL nascent berubah menjadi HDL dewasa yang berbentuk bulat. Agar dapat diambil oleh HDL nascent, kolesterol bebas dibagian dalam makrofag harus dibawa ke permukaan membran sel makrofag oleh suatu transporter yang disebut adenosine triphosphate-binding cassette transporter-1 atau disingkat ABC-1. Setelah mengambil kolesterol bebas dari makrofag, kolesterol bebas akan diesterifikasi menjadi kolesterol ester oleh enzim lecithin cholesterol acyltransferase (LCAT). Selanjutnya sebagian kolesterol ester yang dibawa oleh HDL akan mengambil dua jalur. Jalur pertama ialah ke hati dan jalur kedua adalah kolesterol ester dalam HDL akan dipertukarkan dengan Tg dari VLDL dan IDL. Dengan demikian fungsi HDL sebagai "penyerap" kolesterol dari makrofag mempunyai dua jalur yaitu langsung ke hati dan jalur tidak langsung melalui VLDL dan IDL untuk membawa kolesterol kembali ke hati., ${ }^{14}$ Pada pasien PGK terjadi penurunan enzim LCAT untuk esterifikasi HDL nascent sehingga enzim LCAT tidak dapat mengubah HDL nascent menjadi HDL yang matur. HDL nascent yang belum matur mudah teroksidasi karena tidak stabil sehingga HDL tidak dapat mengambil kolesterol bebas didalam makrofag untuk dibawa ke permukaan membran sel.

Pada Tabel 11 kadar LDL yang didapatkan nilai minimum adalah 28,00 maksimum 211,00 rerata 102,00 menunjukkan hubungan antara kadar LDL dengan 
eLFG. Hasil penelitian di poliklinik GinjalHipertensi RSUP Dr. R. D. Kandou Manado, mendapatkan bahwa terdapat hubungan antara kadar LDL dengan eLFG pada pasien PGK $(\mathrm{p}=0,034)$. Artinya semakin tinggi kadar LDL, semakin rendah nilai eLFG. Studi Lubis, dkk (2005) melaporkan secara statistik bahwa ada hubungan yang bermakna antara LDL dengan PGK $(\mathrm{p}=0,002)$. Proses pembentukan dari LDL yaitu $\mathrm{Tg}$ dan kolesterol yang disintesis di hati dan disekresi ke dalam sirkulasi sebagai lipoprotein VLDL. Dalam sirkulasi, Tg di VLDL akan mengalami hidrolisis oleh enzim lipoprotein lipase (LPL), dan VLDL berubah manjadi IDL yang juga akan mengalami hidrolisis dan berubah menjadi LDL. Sebagian dari VLDL, IDL, dan LDL akan mengangkut kolesterol ester kembali ke hati. LDL adalah lipoprotein yang paling banyak mengandung kolesterol. Sebagian dari kolesterol LDL akan dibawa ke hati dan jaringan steroidogenik lainnya seperti kelenjar adrenal, testis dan ovarium yang mempunyai reseptor untuk kolesterol LDL. Sebagian lagi dari kolesterol LDL akan mengalami oksidasi dan ditangkap oleh reseptor scavenger-A (SR-A) di makrofag dan akan menjadi sel busa (foam cell). Makin banyak kadar kolesterol LDL dalam plasma makin banyak yang akan mengalami oksidasi dan ditangkap oleh sel makrofag. Meningkatnya jumlah LDL kecil padat (small dense LDL) seperti pada sindrom metabolik dan diabetes melitus mempengaruhi keadaan oksidasi termasuk pada PGK. ${ }^{14}$ Pada pasien PGK, small dense LDL atau LDL kecil padat sangat meningkat. small dense LDL merupakan LDL yang kaya akan Tg tetapi small dense LDL belum matur dan mudah teroksidasi dan dapat menyebabkan sumbatan di pembuluh darah karena lemak-lemak yang menempel di pembuluh darah dan lemaklemak tersebut juga dapat menyumbat di pembuluh darah jantung yang menyebabkan serangan jantung. Jadi LDL merupakan prediktor terbaik untuk risiko kardiovaskular pada pasien dengan PGK.

Pada Tabel 12 kadar $\mathrm{Tg}$ yang didapatkan nilai minimum adalah 43,00 maksimum 298,00 rerata 131,30 menunjukkan hubungan antara kadar $\mathrm{Tg}$ dengan eLFG. Hasil penelitian di poliklinik GinjalHipertensi RSUP Dr. R. D. Kandou Manado, mendapatkan bahwa terdapat hubungan antara kadar Tg dengan eLFG pada pasien PGK $(\mathrm{p}=0,030)$. Artinya semakin tinggi kadar $\mathrm{Tg}$, semakin tinggi pula nilai eLFG. Proses pembentukkan Tg yaitu makanan berlemak yang kita makan teridiri atas $\mathrm{Tg}$ dan kolesterol. Selain kolesterol yang berasal dari makanan, dalam usus juga terdapat kolesterol dari hati yang diekskresi bersama empedu ke usus halus. Tg dan kolesterol dalam usus halus akan diserap kedalam enterosit mukosa usus halus. $\mathrm{Tg}$ akan diserap sebagai asam lemak bebas sedang kolesterol tetap kolesterol. Di dalam usus halus asam lemak bebas akan diubah lagi menjadi Tg, sedang kolesterol akan mengalami esterifikasi menjadi kolesterol ester dan keduanya bersama dengan fosfolipid dan apolipoprotein akan membentuk lipoprotein yang dikenal dengan kilomikron. Kilomikron ini akan masuk ke saluran limfe dan akhirnya melalui duktus torasikus akan masuk ke dalam aliran darah. Tg dalam kilomikron akan mengalami hidrolisis oleh enzim lipoprotein lipase yang berasal dari endotel menjadi asam lemak bebas. Asam lemak bebas dapat disimpan sebagai Tg kembali di jaringan lemak, tetapi bila terdapat dalam jumlah yang banyak sebagian akan diambil oleh hati menjadi bahan untuk pembentukkan $\mathrm{Tg}$ di hati. ${ }^{14}$ Kadar kolesterol dan $\mathrm{Tg}$ yang tinggi berperan menimbulkan aterosklerosis. Buruknya sirkulasi ke sebagian besar organ menyebabkan aterosklerosis. Buruknya sirkulasi ke sebagian besar organ menyebabkan hipoksia dan cedera jaringan, serta merangsang reaksi peradangan pada dinding pembuluh darah. Jika terjadi aterosklerosis suplai darah ke ginjal akan berkurang dan dapat menimbulkan gangguan pada LFG dan penurunan fungsi ginjal. 


\section{SIMPULAN}

Terdapat hubungan korelasi negatif bermakna antara kadar kolesterol total serum dengan eLFG $(\mathrm{r}=-0,279, \mathrm{p}=$ 0,039). Tidak terdapat hubungan antara kadar HDL serum dengan eLFG $(\mathrm{r}=$ $0,024, p=0,863$ ). Terdapat hubungan korelasi negatif bermakna antara kadar LDL serum dengan eLFG $(r=-0,287, p=$ 0,034 ). Terdapat hubungan korelasi positf bermakna antara kadar trigliserida serum dengan eLFG $(r=0,293, p=0,030)$

\section{SARAN}

Walaupun hubungan korelasi lemah antara kadar lipid serum dengan eLFG $\mathrm{CKD}_{\mathrm{CK}}$ EPI, sebaiknya dilakukan pengamatan kadar lipid pada pasien PGK.

\section{DAFTAR PUSTAKA}

1. KDIGO. Clinical Practice Guideline for the Evaluation and Management of Chronic Kidney Disease. Kidney International Suplements 2013 volume 3 issue 1 .

2. Suwitra K. Penyakit ginjal kronik. In: Setiati S, Alwi I, Sudoyo AW, Simadibrata M, Setiyohadi B, Syam AF, editors. Buku Ajar Ilmu Penyakit Dalam (6th ed). Jakarta: Interna Publishing, 2014; p. 2159-65.

3. Kidney Disease Outcomes Quality Initiative of The National Kidney Foundation. 2002. Clinical Practice Guidelines for Chronic Kidney Disease: Evaluation, Classification, and Stratification

4. Suardjono, Lydia A. Gagal Ginjal Kronik. In: Buku Ajar Ilmu Penyakit Dalam Jilid II (3rd ed). Jakarta: FKUI, 2009; p. 427-37.

5. Jameson LJ. Harrison's Principles of Internal medicine (12th ed). New York: Mac Graw Hill, New York, 2010.

6. Aggarwal R. Effects of statins on renal function. Mayo Clinic Proceedings;
2007;82(11):1381-90.

7. Bladel ER, Jager RL, Walter D, Cornellssen L, Gallard CA, Boven LA, et al. Platelets of patients with chronic kidney disease demonstrate deficient platelet reactivity in vitro. Bio Med Central Nephrology. 2012;13:127.

8. Simon J, Made M, Poggio ED. Interpreting the estimated glomerular filtration rate in primary care: benefits and pitfalls. Clev Clin J Med 2011; 78(3):189-95.

9. Bermudez RM, Sanjuan JB, Samper AO, Castan JAB, Garcia G. Assesment of Bermudez RM, Sanjuan JB, Samper AO, Castan JAB, Garcia G. Assesment of the new CKD-EPI equation for estimating glomerular filtration rate. Nefro J 2010;30(2): 185-94.

10. Delanaye P, Cavalier E, Mariat C, Maillard N, Krzesinski JM. MDRD or CKD-EPI study equations for estimating prevalence of stage 3 CKD in epidemiological studies: which difference?Is this difference relevant? BMC Nephrol. 2010;11(8):1-7.

11. Schier RW. Role of diminished renal function in cardiovascular mortality. Marker or patgogenetic factor? Journal of the American college of Cardiology. 2006;47(1):1-8.

12. Ardhanari S, Alpert MA, Aggarwal $K$ Cardiovascular Disease in Chronic Kidney Disease: Risk Factors, Pathogenesis, and prevention. Advances in Peritoneal Dialysis. 2014;(30):40-53.

13. Sundaram SPM, Nagarajan S, Vefi AJM. Chronic Kidney Disease-Effect of Oxidative Stress. Chinese Journal of Biology. 2014:1-6.

14. Daugirdas JT, Blake PG, Ing TS. Handbook of Dialysis (4th ed). Phildelphia: Lipincott William \& Wilkins. 2007. 